\title{
Ideal and Beyond:
}

\section{Idealist International Relations Theory Contrast to Realist One}

\section{Hakan Mehmetcik}

Hakan Mehmetcik, 32, is a graduate student who received his BA in "International Relations" at the Istanbul University, in Turkey, in 2006. In 2009, he obtained an MA in Economics at the Dalarna University, and another MS in Eurasian Studies at the Uppsala University in 2010, in Sweden. He currently studies at the Yildir. Technical University as a Ph.D. student and works as a research assistant at the Department of International Relations at Isike University in Turkey. His interests cover security studies, regionalism, theory of international relations and peace and conflict studies in general. On his Ph.D. studies, he specializes on coercive diplomacy, deterrence and nuclear extended deterrence issues.

\begin{abstract}
There is now a substantial body of theory on international relations. However, to understand theories of International Relations, we need to focus on the history of the discipline, which somehow always starts with idealist theory of International Relations. Therefore, it is worth to plunging into the debate on the structure of idealist International Relations theory to grab the essence of the dynamics and aims of the attempts that theorists try to address in the International Relations. This effort also consists of finding out the use and abuse of theory within the discipline as an attempt to point out the myth functions in International Relations theories. The paper aims to present idealist theory of International Relations by pinpointing differences with realist impulses on human nature, the nature of international relations, and cyclical view of history.
\end{abstract}

Keywords: Idealist International Relations Theory; Theory of International Relations; Realist Idealist Debate 


\section{Introduction}

There are certain debates on International Relations. The first debate is on the context of IR. What is the study of IR? Is it about just the relations between states or does it consist of many other things? Some argues that it was about international relations, yet as globalization push forward now it consists of many other relations and actors. Even some argues the very name of international relations should be changed (Holsti 1985). Is it a science or an art? What should an IR scholar focus on and how should he/she do that? These sorts of questions are common for all social sciences while it is more relevant for IR. Wight argues that IR is not a science (but a pseudoscience as Kuhn put it) and therefore there is no international relations theory (Wight 1960). Who are the main actors? What are the borders of IR with other disciplines such as History, Economics, or Sociology? All these are interrelated with the debates of behaviorists and traditionalists. The second debate is on the discipline itself (Schmidt 1997). When did it flourish? Where did it start and why there? Some argue that it flourished in ancient Greek city states (Eralp 1996:37) as some others argue that its roots could be detected back at the times after the French Revolution (Derian 1998:3). There are views that point to its beginning at the Westphalia Peace, which led the birth of modern nation states (Bull 1972:30-55) as another very large group of scholars argue that it has started in the early 1900s. This "debate culture" has been so penetrated within the discipline that the history of the discipline has always been explained by some uncertain and imperceptible debates — the so called "great debates" (Maghroori and Ramberg 1982; Arend 1974; Derian 1998; Holsti 1985; Viotti and Kauppi 1998).

Idealist international relations theory is a by-product of one of these so-called great debates in the discipline. Even though there is no one who calls himself an idealist (Dunne, Kurki, and Smith 2010), idealist theory of IR has rich historical roots which uncover both the history of the discipline and most of the answers to the questions above. Therefore it is not just a coincidence that almost any book on IR theories starts with idealist IR theory. However, as like everything that we talk about, everything that we regard as existing, has an opponent, an anti-thesis as Marx put it using a Hegelian philosophy (Kaufmann 1988). Idealist theory has its own-realism —and the best way to understand idealism is to compare to realist IR theory. With regard to this interpretation, in this work, I aim to explain idealist theory by contrast to realism. To do that, however, I will touch upon firstly the history and the context of the conditions that bring up idealist theory at the beginning of the early 1900s as a first theory of IR and the reasons that pave the way for idealist return after the end of the Cold War. 


\section{The Birth of Idealist Theory}

Every theory is a child of its time (Maalouf 2011:170). It is, thus, highly instructive to look at the conditions that pave the way for a theory emerging as a tool for understanding the essence of dynamics in world affairs. Therefore, it is crucial to evaluate the history of the discipline to understand any IR theory. In this sense, IR is a child of early 1900s as a scientific discipline beginning in 1919 in the aftermath of the First World War just as like idealism as a child of the same times. The first Department of International Politics was founded at Aberystwyth University in the United Kingdom. A similar development was taking place in the United States in 1919. Just months after the establishment of the first department of IR in UK, Georgetown University founded the Edmund A. Walsh School of Foreign Service, the oldest program in International Relations in this country, whose initial aim was actually to provide education for the prospective diplomats. In 1920, the London School of Economics followed suit, founding its own Department of International Relations and, in 1928, the University of Chicago founded the Committee on International Relations as its own department of IR. After these first attempts to boost scientific support for world peace, within a decade more than ten schools had been established. The aim was simple - to prevent any other possible devastation like World War I. Even David Davies, who was an industrialist and supported the first department at the Aberystwyth University by a huge financial support, indented bringing worldwide peace and preventing future war. Sir Alfred Zimmern, the first holder of the chair in this very first faculty of IR at that department as well as the most polished idealist writers of his time, pursued this pacifist vision eagerly (Markwell 1986). They all were very much men of their time, products of the pacifistic tendencies of the interwar period. There were other attempts as well. Establishing international organizations such as the League of Nations, which was the first international organization whose principal mission was to maintain world peace, was one of them. The President of the USA, Woodrow Wilson was one of the leading statesman who promoted idealism and his 14 points was kind of "Magna Carta" for idealist agenda. Even popular movies of the era, such as "All Quiet on the Western Front" promoted the view that war was futile and should never happen again (Milestone 1930). It is not a surprised that Norman Angell's book Great Illusions, (Angell 2009), one of the best-known works prior to WWI, argued that war became futile between industrial nations because it did not pay off. All in all, at the backbone of idealist birth lays the necessity of the times. Just after the devastation of World War I, scientist, leaders, artists, human rights promoters, civil societies and all others could only think about preventing another devastation by being equipped with international law, institutions, and peaceful engagement believing in idealism. 


\section{The Core of Idealist Theory With Contrast to Realism}

Nonetheless, the idealist agenda was not enough to prevent upcoming wars and devastations. All of a sudden many turned their back to idealism and started speaking the realist language with the beginning of World War II. E.H. Carr, a British Scholar, one of the father of realist theory of IR, the producer of the very name "idealist", criticized idealists as being "utopian" who profoundly misread the facts of history and misunderstood the nature of international relations (Carr 2001). According to him, international relations are far more about conflict than about cooperation (Jackson and Sørensen 2010:37). The other realist scholars followed suit one after another such as Morgenthau, Niebuhr, Kennan, Wolfers, etc. Here I will not plunge into the realist inside debates or their assumptions on the world politics. Some of what is proposed by realism, however, is the key to understand, I think, very core of idealist assumptions. In this regard, lets look at basic assumptions of idealism on light of realist critics within three categories: human nature, the nature of international relations, and cyclical view of history.

The first assumption is on human nature. In particular, in Morgenthau's writing, human nature plays an important role in the reason to understand why international politics is so conflictual. Using Hobbes interpretation of "state of nature" in which human life is poor, nasty, brutish and short (Hobbes 2013), Morgenthau puts the absolute centrality of power relations in his scheme of human affairs (Morgenthau, Thompson, and Clinton 2005). As a result of this interpretation of human nature realists see international affairs as power politics in which every states takes part on their own. It was not difficult to find evidence to think in this way in the late 1930s. On the other hand, idealist thought that human nature is actually changeable using Kant's argument on human philosophy. Kant basically argues that we all shape our experience of things through the filter of our mind. That is, it is possible to determine our future experience, that is, it is possible to teach and learn peace, in practical terms. Furthermore, in a well-known essay, "Perpetual Peace: A Philosophical Sketch" Kant described his proposed peace program. Perpetual peace is arguably seen as the point of departure for idealist agenda. But later on, one of the most important figure in the Neo-Realist circles, Kenneth Waltz, would argue that even if it is possible to spread peace through educations, institutions, laws, any state could not wait for that times comes and trust such an agenda to leave its security (Waltz 2001). In a similar fashion, Niebuhr pointed out that realists (the children of darkness) are evil because they know no law beyond the self. They are wise, though evil, because they understand the power of self-interest. Idealists (the children of light) are virtuous because they have some conception of a higher law than their own will. They are usually foolish because they do not know the power of self-will. They 
underestimate the peril of anarchy in both the national and the international community (Niebuhr 2011).

The second assumption is on the nature of international relations. Realists see international politics, like all politics, as a struggle for power. As long as there is no supreme power, no higher authority and no world government, international politics would be anarchic in which sovereign and armed states faces each other. So, the regularity element in this system of state is "international anarchy". Sole response of states to this international anarchy rhetoric, from a realist point of view of course, is to maintain power to secure survival and other national interests within a self-help system (Morgenthau, Thompson, and Clinton 2005; Waltz 2010; Mearsheimer 2003; Bull 2002). For idealist, there are reasons to believe in the other way around, since international relations, from an idealist point of view, are not just about a struggle for power and survival or simply national interests. Therefore, there are many ways to tame the conflictual aspects of international politics through trade, international laws, and international institutions, building trust and cooperation, mutual benefits and understanding. Liberal idealists or democratic peace theorists argue that there are many reasons to believe that international relations could be tamed. For instance, Russett and Oneal describe a "Kantian Triangle" which consists of democracies, international institutions and economic interdependence. For the past couple of decades, all these three phenomena are rising by mutually reinforcing each other and by creating multidirectional relations among both sates and non-states actors (Oneal and Russett 2000). Thus, there are many reasons to believe that international relations are more about cooperation than conflicts.

The last assumption is the cyclical view of history. For realist, history is nothing more than a vicious circle. Each generation tends to make the same mistake as previous generations have done (Jackson and Sørensen 2010:39). Change is possible only in terms of balance of power. Contrary to this pessimistic view of realism, idealists see that qualitative change for the better is possible. Hegel regarded history as progressive and reason (freedom) was something that would self-actualize in the world. Freedom, the essence of reason, was to be realized along with the development of history. Departing from this Hegelian reading of progressive history, Fukuyama even claimed that Western liberal democracy is the final form of human government (Fukuyama 2006). In sum, idealist view of history is a progressive one (a journey from good to the best) which is to be seen as bringing global peace. 


\section{Conclusion}

Popular wisdom during the early period of the academic discipline of IR was that international peace was only possible if classical ideas about the balance of military power were replaced by a system of collective security. President Woodrow Wilson famously articulated similar ideas in his 1918 "Fourteen Points" speech, which later became the foundation for the League of Nations. The key issues emphasized by Wilson were the need for open diplomacy, a reduction in armaments "to the lowest point consistent with domestic safety," and respect for the territorial integrity of all sovereign states. (Burchill et al., 2013). However, Robert D. Kaplan warns us about these kinds of expectations that emerged after almost all victories. He argues that "Victory in World War I saw a burst of such idealism under the banner of "Wilsonianism," a notion that took little account of the real goals of America's European allies and even less account of the realities in the Balkans and the Near East, where democracy and freedom meant heightened ethnic awareness. The same pattern followed the West's victory in the Cold War, which many believed would bring simply freedom and prosperity under the banners of "democracy" and "free markets." But just as after World War I and World War II, our victory has ushered in the next struggle for survival, in which evil wears new masks.”(Kaplan, 2001: xi). Layne points out that wars had been usually avoided not because of peaceful dispute resolution as democratic peace theories suggest but because of the factors that realist school of IR bring about such as deterrence, coercion and force (Layne1994). And finally Mead draws our attention to that latest developments suggest old power politics back on the stage by saying "So far, the year 2014 has been a tumultuous one, as geopolitical rivalries have stormed back to center stage. Whether it is Russian forces seizing Crimea, China making aggressive claims in its coastal waters, Japan responding with an increasingly assertive strategy of its own, or Iran trying to use its alliances with Syria and Hezbollah to dominate the Middle East, old-fashioned power plays are back in international relations." (R. Mead, 2014). Or in a similar direction Robert Kagan put it as following "Hopes for a new peaceful international order after the end of the Cold War have been dashed by sobering realities: Great powers are once again competing for honor and influence. Nation-states remain as strong as ever, as do the old, explosive forces of ambitious nationalism. The world remains "unipolar," but international competition among the United States, Russia, China, Europe, Japan, India, and Iran raise new threats of regional conflict. Communism is dead, but a new contest between western liberalism and the great eastern autocracies of Russia and China has re-injected ideology into geopolitics. Finally, radical Islamists are waging a violent struggle against the modern secular cultures and powers that, in their view, have dominated, penetrated, and polluted their Islamic world. The grand expectation that after 
the Cold War the world would enter an era of international geopolitical convergence has proven wrong." (Kagan, 2009:115).

All these interpretation of the world affairs are byproduct of very core assumptions on human nature, the nature of international relations, and cyclical view of history, on which idealists and realists differ greatly. Jean-Jacques Rousseau described a situation in which five primitive man go out for a hunt. At this group of people hunting a stag collectively, a hare comes within the reach of one hunter. He can certainly get the hare by himself, but this action would ruin the stag hunt. Rousseau argues that he would ruin the hunt in any way: "If it was a matter of hunting a deer, everyone well realized that he must remain faithful to his post; but if a hare happened to pass within reach of one of them, we cannot doubt that he would have gone off in pursuit of it without scruple..." (Rousseau 2010:98)

This is taken to be an important analogy for realist to explain why cooperation is not possible. What if, then, we try to complete the story? What would happen the day after the hunt? The hunter who hunts the hare would be hungry again. The rest of the group would be angry with him for obvious reasons. Would he not regret what he had done on hunting day? Would he not try to convince the others come together and go out for hunt again? There are thousands of possibilities that you can find. However, it all depends on your perception. Like it depends on which theory you would choose to explain and understand international relations.

Robert Cox claims that every theory speaks for someone and for some purpose (Cox 1981). Cynthia Weber proclaimed that if IR theory narrates a particular view of the world from the perspective of various IR traditions, an IR myth is what helps make a particular view of the world appear to be true. The myth function in IR theory is the transformation of what is particular, cultural, and ideological (like a story told by an IR tradition, or a story Rousseau told us) into what appears to be universal, natural, and purely empirical. It is naturalizing meanings, making them into common sense, that are the products of cultural practices. Put another way, the myth function in IR theory is making a fact out of an interpretation (Weber 2009:6-7). The debate between realism and idealism does the same thing in the same way. It naturalizes different meanings, by making them into different common sense, that are the products of different cultural practices. That is, they create different myth functions in IR theory to make a fact out of an interpretation. 


\section{Bibliography}

Angell, Sir Norman. 2009. The Great Illusion, 1933: A Summarized and Rearranged Version of “the Great Illusion” Published in 1910. Cornell University Library.

Arend, Lijphart. 1974. "International Relations Theory: Great Debates And Lesser Debates." International Social Science Journal 26: 11-21.

Bull, Hedley. 1972. "The Theory of International Politics, 1919-1969.” In Brian Porter The Aberystwyth Papers: International Politics 1919-69, Second Edition. Oxford: Oxford University Press.

- 2002. The Anarchical Society. 3rd ed. Columbia University Press.

Burchill, Scott et al., 2013. Theories of International Relations, 5th edition. New York: Palgrave Macmillan.

Carr, E. H. 2001. The Twenty Years' Crisis 1919-1939: An Introduction to the Study of International Relations. Edited by Michael Cox. Palgrave Macmillan.

Cox, R. W. 1981. "Social Forces, States and World Orders: Beyond International Relations Theory." Millennium - Journal of International Studies 10 (2): 126-55. doi: 10.1177/03058298810100020501.

Derian, James Der. 1998. International/Intertextual Relations: Postmodern Readings of World Politics. Edited by Michael J. Shapiro. 1st Edition. Lexington Books.

Dunne, Tim, Milja Kurki, and Steve Smith. 2010. International Relations Theories: Discipline and Diversity. Second Edition. Oxford University Press, USA.

Eralp, Atilla. 1996. Devlet, Sistem ve Kimlike: Uluslararası Ilişskilerde Temel Yaklaşımlar. Atilla Eralp. istanbul: İletişim.

Fukuyama, Francis. 2006. The End of History and the Last Man. Reprint. Free Press.

Hobbes, Thomas. 2013. Leviathan. Empire Books.

Holsti, K. J. 1985. The Dividing Discipline: Hegemony and Diversity in International Theory. HarperCollins Publishers Ltd.

Jackson, Robert, and Georg Sørensen. 2010. Introduction to International Relations: Theories and Approaches. Fourth Edition. Oxford University Press, USA.

Kaplan, Robert D., 2001. The Coming Anarchy: Shattering the Dreams of the Post Cold War, Reprint edition, New York: Vintage.

Kagan, Robert, 2009. The Return of History and the End of Dreams, Vintage edition, New York: Vintage.

Kaufmann, Walter. 1988. Hegel: A Reinterpretation. University of Notre Dame Press. 
Layne, Christopher 1994. "Kant or Cant: The Myth of the Democratic Peace," International Security 19(2) (October 1,1994): 5-49.

Maalouf, Amin. 2011. Disordered World: Setting a New Course for the Twenty-First Century. Tra. Bloomsbury USA.

Maghroori, Ray, and Bennett Ramberg. 1982. Globalism versus Realism: International Relations' Third Debate. Westview Press.

Markwell, D. J. 1986. "Sir Alfred Zimmern Revisited: Fifty Years On.” Review of International Studies 12 (4): 279-92. doi:10.2307/20097090.

Mead, Walter R., 2014. "The Return of Geopolitics: The Revenge of the Revisionist Powers," Foreign Affairs 93(4): 115-25.

Mearsheimer, John J. 2003. The Tragedy of Great Power Politics. Reprint. W. W. Norton \& Company.

Milestone, Lewis. 1930. All Quiet on the Western Front. Drama, War.

Morgenthau, Hans, Kenneth Thompson, and David Clinton. 2005. Politics Among Nations. 7th ed. McGraw-Hill Humanities/Social Sciences/Languages.

Niebuhr, Reinhold. 2011. The Children of Light and the Children of Darkness: A Vindication of Democracy and a Critique of Its Traditional Defense. University Of Chicago Press.

Oneal, John R., and Bruce Russett. 2000. Triangulating Peace: Democracy, Interdependence, and International Organizations. W. W. Norton \& Company.

Rousseau, Jean Jacques. 2010. A Discourse On Inequality. Kessinger Publishing, LLC.

Schmidt, Brian C. 1997. The Political Discourse of Anarchy: A Disciplinary History of International Relations. State University of New York Press.

Viotti, Paul R., and Mark V. Kauppi. 1998. International Relations Theory: Realism, Pluralism, Globalism and Beyond. 3rd ed. Pearson.

Waltz, Kenneth N. 1979. Theory of International Politics. 1st ed. Waveland Press Inc.

- 2001. Man, the State, and War: A Theoretical Analysis. Revised. Columbia University Press.

Weber, Cynthia. 2009. International Relations Theory: A Critical Introduction. 3rd ed. Routledge.

Wight, Martin. 1960. "Why Is There No International Theory?” International Relations 2(1): 35-48. doi: $10.1177 / 004711786000200104$. 